\title{
Relations between plasma non-esterified fatty acid metabolism and body tissue mobilization during chronic undernutrition in goats
}

\author{
BY F. R. DUNSHEA* AND A. W. BELL* \\ School of Agriculture, La Trobe University, Bundoora, Victoria 3083, Australia \\ AND T. E. TRIGG† \\ Animal and Irrigated Pastures Research Institute, Kyabram, Victoria 3620, Australia
}

(Received 15 January 1988 - Accepted 29 June 1988)

\begin{abstract}
1. Eleven mature goats were offered $140 \mathrm{~kJ}$ metabolizable energy $/ \mathrm{kg}$ per d (M) of lucerne (Medicago sativa) hay-oaten grain $(1: 1, \mathrm{w} / \mathrm{w})$ for at least 1 month before plasma non-esterified fatty acid (NEFA) kinetics and tritiated water space (TS) were determined.

2. Goats were then fed at $\mathrm{M}, 0.5 \mathrm{M}$ or $0.25 \mathrm{M}$ for 34 (SE 6) d, at which time the experimental procedures were repeated.

3. Chronic undernutrition resulted in elevated NEFA concentrations and NEFA entry rate, with a tendency for the ratio plasma NEFA:glycerol to increase, suggesting that body-fat mobilization during prolonged underfeeding is due more to decreased lipogenesis and intracellular NEFA re-esterification rather than to increased lipolysis.

4. Plasma NEFA concentrations and NEFA entry rate, as well as being highly correlated with each other, were significantly related to calculated energy balance and body fat losses estimated from changes in live weight and TS.

5. Increases in NEFA entry rate were highly correlated with, and of the same magnitude as, body fat losses, confirming that NEFA kinetics do quantitatively reflect lipid mobilization.
\end{abstract}

It is well established that plasma non-esterified fatty acid (NEFA) concentrations are markedly elevated during acute energy restriction in ruminants (Annison, 1960; Patterson et al. 1964; Di Marco et al. 1981; Hassan \& Musa, 1984). This is due to increased mobilization of adipose-tissue lipid in the form of NEFA. Plasma concentrations of NEFA are also elevated, to a lesser extent, during more prolonged undernutrition, and plasma NEFA concentrations have been suggested as indices of chronic energy status (Holmes \& Lambourne, 1970; Russel \& Wright, 1983). Other workers have attempted to estimate energy status in chronically undernourished animals by monitoring live weight or body composition, or both. The inverse relation between body water, estimated by tritiatedwater (TOH) dilution, and body fat has been used to assess indirectly changes in body fat in the same animals (Panaretto, 1964, 1968; Farrell et al. 1972). However, to date no one has attempted to determine whether the magnitude of changes in NEFA kinetics are quantitatively similar to changes in body fat in chronically undernourished ruminants.

The aims of the present series of experiments, conducted on non-lactating, non-pregnant goats, were to determine whether (1) TOH-dilution techniques are sensitive enough to quantify small changes in body composition in response to chronic undernutrition, (2) plasma NEFA or glycerol concentrations or NEFA entry rates accurately reflect energy status, (3) changes in fat mobilization estimated by TOH dilution and NEFA kinetics are quantitatively similar.

Present addresses: * Department of Animal Science, Cornell University, Ithaca, NY 14853, $†$ Peptide Technology, PO Box 444, Dee Why, NSW 2099, Australia. 


\section{MATERIALS AND METHODS \\ Animals and levels of feeding}

Eleven non-lactating, non-pregnant Saanen does aged 46 years and weighing $38-62 \mathrm{~kg}$ were housed indoors in thermoneutral conditions for at least 1 month before experiments began. During this time they were fed at 2-h intervals on a ration of lucerne (Medicago sativa) chaff-oaten grain $(1: 1, \mathrm{w} / \mathrm{w})$ to provide $140 \mathrm{~kJ}$ metabolizable energy $(\mathrm{ME}) / \mathrm{kg}$ per $\mathrm{d}(\mathrm{M})$. Goats were weighed twice weekly and regression analysis confirmed that in all animals live weight remained constant during this period.

After determining NEFA entry rate and TOH dilution the goats were introduced to one of three chronic feeding regimens. Three animals were kept at $\mathrm{M}$, three received $70 \mathrm{~kJ} \mathrm{ME} /$ $\mathrm{kg}$ per $\mathrm{d}(0.5 \mathrm{M})$ and five were given $35 \mathrm{~kJ} \mathrm{ME} / \mathrm{kg}$ per $\mathrm{d}(0.25 \mathrm{M})$. The goats remained on these feeding levels for 34 (SE 6) d at which time the experimental procedures were repeated.

Five of these does, and an additional six does were slaughtered and their chemical body compositions were determined to develop regression equations relating body composition to $24 \mathrm{~h}$ fasted live weight (FLWT) and TOH space (TS).

\section{Measurements}

Infusions. At least $24 \mathrm{~h}$ before an infusion, polyethylene catheters $(0 \cdot 80 \mathrm{~mm}$ i.d., $1.20 \mathrm{~mm}$ o.d.; Dural Plastics, Australia) were inserted into both external jugular veins using 16 gauge needles (Medicut; Medishield, USA). The infusion catheter was inserted approximately $200 \mathrm{~mm}$ while the contralateral sampling catheter was inserted approximately $80 \mathrm{~mm}$. Catheters were kept patent by daily flushing with sterile saline $(9 \mathrm{~g}$ sodium chloride/l) containing heparin $(500 \mathrm{U} / \mathrm{ml})$ and were sealed with stainless-steel pins. Between samples taken during $1{ }^{14} \mathrm{C}$-labelled NEFA infusions, the catheters contained sterile saline only.

All NEFA infusates contained an equimolar mixture of $\left[1-{ }^{14} \mathrm{C}\right]$ palmitic, stearic and oleic acids $(56-57 \mathrm{mCi} / \mathrm{mmol}$; Amersham,Bucks) and were prepared by a modification of the method of Lindsay \& Leat (1977). Briefly, to $60 \mu \mathrm{Ci}$ mixed NEFA in ethanol $(30 \mu \mathrm{Ci} / \mathrm{ml})$ were added $3 \mathrm{mg}$ each of carrier palmitic, stearic and oleic acids and $10 \mu 11 \mathrm{M}$-potassium hydroxide. After drying under a gentle stream of nitrogen gas, $10 \mathrm{ml}$ warm saline $\left(60^{\circ}\right)$ was added and the potassium soaps of the NEFA were dissolved by maintaining this solution at $60^{\circ}$ for $30 \mathrm{~min}$. The solution was filtered through a $0.22 \mu \mathrm{m}$ disposable filter (Millex-GS; Millipore, Ma., USA) into $15 \mathrm{ml}$ plasma freshly obtained from the experimental goat, and which was gently stirring on a magnetic hotplate at $40^{\circ}$. The infusate was diluted to $50 \mathrm{ml}$ with saline and drawn into a $50 \mathrm{ml}$ disposable syringe. Infusions were performed using a syringe pump (Vial Medical, France) at $12.5 \mathrm{ml} / \mathrm{h}(0.25 \mu \mathrm{Ci} / \mathrm{min})$ for $3.5 \mathrm{~h}$. Blood sampling $(10 \mathrm{ml})$ for plasma NEFA concentrations and specific radioactivity (SRA) and glycerol concentrations, commenced after $90 \mathrm{~min}$ and eight blood samples were taken at equally spaced intervals over the next $120 \mathrm{~min}$.

Immediately after the $1-{ }^{14} \mathrm{C}$-labelled NEFA infusion the goats were weighed, and feed and water were removed. After $18 \mathrm{~h}$ a blood sample was taken to determine background or residual TOH SRA. A single dose of TOH in saline $(5 \mu \mathrm{Ci} / \mathrm{kg}, 20 \mu \mathrm{Ci} / \mathrm{ml})$ was rapidly administered via a jugular catheter, followed immediately by $20 \mathrm{ml}$ saline. A blood sample was taken $6 \mathrm{~h}$ later (Searle, 1970), and the goats were weighed and either introduced to their chronic feeding regimen or slaughtered for subsequent chemical analyses.

Plasma analyses. Blood samples were collected into syringes containing $\mathrm{Na}_{2}$ EDTA $(1 \mathrm{~g} /$ 1), sealed and immediately stored on ice. Within $1 \mathrm{~h}$ of sampling, blood was centrifuged for $15 \mathrm{~min}$ at $2000 \mathrm{~g}$ and $4^{\circ}$ to obtain plasma. For determination of plasma NEFA concentration and SRA the plasma lipids were extracted within $1 \mathrm{~h}$. Plasma for other analyses was stored at $-20^{\circ}$. 
Plasma NEFA were isolated by a modification of the back-extraction method of Pethick et al. (1983). The modification was that $\left[9,10(n)-{ }^{3} \mathrm{H}\right]$ palmitic acid $(1 \mathrm{nCi}, 500 \mathrm{mCi} / \mathrm{mmol}$; Amersham) was added to the plasma to determine recovery of extracted and derivatized NEFA. Isolated NEFA were converted to their methyl esters by refluxing in $2.0 \mathrm{ml}$ sulphuric acid in methanol $(70 \mathrm{~g} / \mathrm{l})$ for $2 \mathrm{~h}$. Heptane $(4 \mathrm{ml})$ and $1.0 \mathrm{ml} \mathrm{NaCl}(40 \mathrm{~g} / \mathrm{l})$ were added with mixing and the heptane layer containing the fatty-acid methyl esters was transferred to a scintillation vial. Heptane was removed by evaporation under a gentle stream of $\mathrm{N}_{2}$ gas and the fatty-acid methyl esters were reconstituted in $25 \mu 1$ heptane. Duplicate $0.5 \mu \mathrm{l}$ samples were injected on to a $2 \mathrm{~m} \times 3 \mathrm{~mm}$ glass column packed with $10 \%$ SP-216-PS on 100 110 mesh Supelcoport (Supelco, Pa., USA) in a Perkin Elmer F 11 chromatograph at $165^{\circ}$. The molar concentrations of the individual NEFA were determined by comparison with the iniernal standard (150 nmol pentadecanoic acid; Sigma, Mo., USA) and use of appropriate correction factors. The remainder of the sample was dissolved in $5.0 \mathrm{ml}$ scintillation fluid (Anderson \& MacClure, 1973) and radioactivity counted using a Packard Tri-Carb $460 \mathrm{C}$ liquid-scintillation system set in the dual-label mode. Recovery of $\left[9,10(n)-{ }^{3} \mathrm{H}\right]$ palmitic acid was $75-80 \%$ complete. Infusate radioactivity was determined after solubilizing $50 \mu \mathrm{l}$ infusate in $100 \mu \mathrm{l}$ solubilizing agent (Protosol; New England Nuclear, Ma., USA).

Plasma glycerol was determined by the glycerol dehydrogenase (EC 1.1.1.6) method described by Boobis \& Maughan (1983). TOH SRA was determined by liquid scintillation counting of duplicate $0.5 \mathrm{ml}$ samples of plasma water obtained after lyophilization of plasma.

Slaughter and body composition. Before slaughter the goats were weighed, shorn and then reweighed. A lethal dose of sodium pentobarbitone was given intravenously and the animal was bled out. Blood was weighed, then discarded, and assumed to contain $(\mathrm{g} / \mathrm{kg}) 819,1$, 83 and 171 water, fat, ash and protein respectively (Brown \& Taylor, 1986). Hooves and gastrointestinal tract (GIT) contents were removed, weighed and the latter mixed before a subsample was taken for dry matter (DM) determination. The body to be analysed, which consisted of the whole body less hair, hooves and GIT contents, was stored at $-15^{\circ}$ in plastic bags until body composition was determined. The empty body (EB) was defined as this frozen tissue plus blood. Losses during manipulative stages were assumed to comprise entirely water, and accounted for 12.1 (SE 1 ) g/ $\mathrm{kg}$ live weight. The frozen body was weighed, cut into small pieces with a bandsaw and minced through four progressively smaller endplates. The final endplate had 5-mm holes. After each pass through the mincer the tissue was thoroughly mixed by hand. The DM contents of the minced tissue and GIT contents were determined by oven-drying ( $105^{\circ}$ for $48 \mathrm{~h}$ ) triplicate $80 \mathrm{~g}$ or $300 \mathrm{~g}$ subsamples respectively. The dry-tissue samples were then ashed in a muffle furnace at $600^{\circ}$ for $12 \mathrm{~h}$. Fat was determined in $6 \times 10 \mathrm{~g}$ samples of freeze-dried minced tissue using the chloroform-methanol-water extraction method of Aitkinson et al. (1972). As the $\mathrm{N}$ content of tissue protein is variable and difficult to determine (Bird et al. 1982; Benedict, 1987), tissue protein was calculated by difference, i.e. protein $=D M-($ fat + ash $)$.

Calculations and statistics. Whole-body NEFA entry rate was calculated by dividing the infusion rate (disintegrations/min $(\mathrm{dpm})$ per $\mathrm{h}$ ) of the mixture of $1-{ }^{14} \mathrm{C}$-labelled NEFA by the SRA of plasma NEFA after the latter was no longer time-dependent. The rise to plateau SRA occurred rapidly, particularly in underfed animals, and in all goats was achieved within $1 \mathrm{~h}$ (Fig. 1). A cyclical pattern in plasma NEFA concentrations and SRA was evident, even in goats fed at maintenance. During severe undernutrition these fluctuations were more marked, making it very difficult to determine mean NEFA levels and SRA. To minimize this the eight NEFA concentrations and SRAs obtained in each sampling period $(2 \mathrm{~h})$ were averaged in logarithmic units, in which there was greater homogeneity of variance (Patterson et al. 1964). However, there was no indication that a similar 


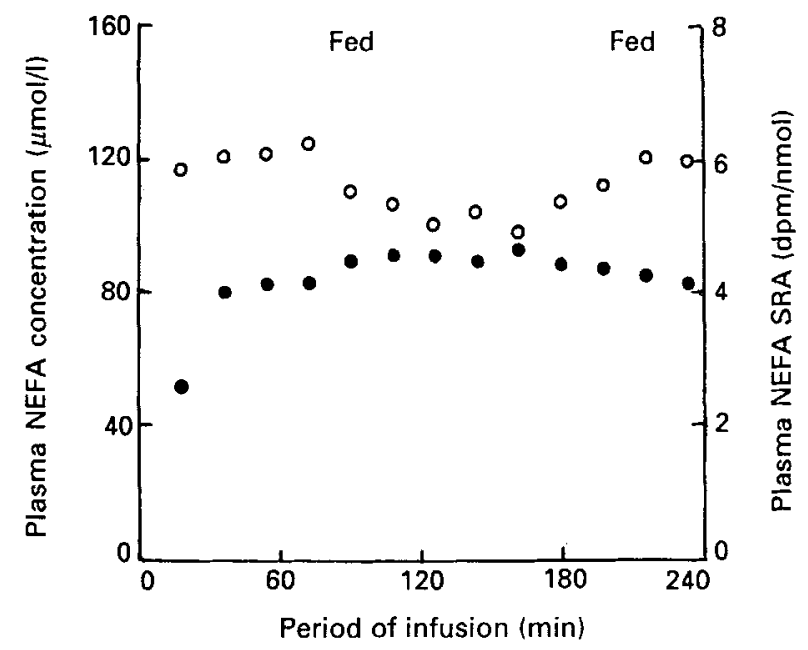

Fig. 1. Plasma non-esterified fatty acid (NEFA) concentration $(O)$ and specific ratioactivities (SRA) (O) during a continuous infusion of $\mathrm{I}^{14} \mathrm{C}$-labelled NEFA in a goat fed on $140 \mathrm{~kJ}$ metabolizable energy $/ \mathrm{kg}$ per d. dpm, Disintegrations/min.

transformation was necessary to achieve approximate normality in the variation between animals and they were therefore analysed in natural units.

Maintenance requirements were assumed to be $0.312 \mathrm{~kJ} \mathrm{ME} / \mathrm{kg}$ live weight ${ }^{0.75}$ per $\mathrm{d}$ (Armstrong \& Blaxter, 1965) and the ME content of the diet was calculated from the organic matter $(\mathrm{OM})$ digestibility of the diet determined in four of the goats fed at $\mathrm{M}$ during the week preceding the first infusion (Ministry of Agriculture, Fisheries and Food, 1975). The ME content of the diet calculated in this manner was $10 \cdot 1$ (SE 0.1) MJ ME/ $\mathrm{kg} \mathrm{DM}$.

Statistical analyses were performed using Minitab version 5.1 (Ryan et al. 1985) and Statistical Analysis System (SAS, 1982). Treatment effects on plasma constituents, NEFA eniry rate and changes in body composition were assessed using analysis of variance. Since in some cases homogeneity of variances could not be shown, the more conservative paired $t$ tests were used to contrast effects of feeding level. Both linear and allometric regression models were used to develop prediction equations for body composition. These equations included only those predictors that could be measured in vivo, i.e. FLWT and TS.

\section{RESULTS}

\section{NEFA kinetics}

Initially two of the goats did not eat their full ration, consuming only approximately $100 \mathrm{~kJ} \mathrm{ME} / \mathrm{kg}$ per $\mathrm{d}$, and exhibited high plasma NEFA concentrations and NEFA entry rate. Therefore, as it was likely that these animals were mobilizing tissue reserves at the time of the initial measurements, their values were excluded from all analyses except the regressions between plasma NEFA concentrations, NEFA entry rate and calculated energy balance (Figs 2 and 3). Also, plasma from one goat in the $M / M$ group was exhausted when determining TOH SRA and so changes in EBF could not be estimated.

NEFA entry rate was significantly increased when feed intake was decreased from $M$ to $0.5 \mathrm{M}(P<0.05)$ and both plasma NEFA concentrations and NEFA entry rate were increased when feed intake was decreased from $\mathrm{M}$ to $0.25 \mathrm{M}(P<0.001)$ (Table 1). There were no effects of chronic undernutrition on plasma glycerol concentrations.

Plasma NEFA concentrations were highly correlated with whole body NEFA entry rate (Fig. 2, $R^{2} 0 \cdot 70, P<0.001$ ) and with calculated energy balance (Fig. 3, $R^{2} 0 \cdot 80, P<0 \cdot 001$ ). 
Table 1. Plasma metabolite concentrations and non-esterified fatty acid (NEFA) entry rate in three groups of goats before and after energy intake was changed from $140(M)$ to 140 $(\mathrm{M}), 70(0.5 \mathrm{M})$ or $35(0.25 \mathrm{M}) \mathrm{kJ}$ metabolizable energy/ $\mathrm{kg}$ per $d$ ( $\mathrm{n} 3$ for each group)

\begin{tabular}{|c|c|c|c|c|c|}
\hline & Before & After & Difference & $\begin{array}{c}\text { SED } \\
(2 \mathrm{df})\end{array}$ & Probability* \\
\hline \multicolumn{6}{|c|}{ Plasma NEFA $(\mu \mathrm{mol} / 1)$} \\
\hline $\mathrm{M} / \mathrm{M}$ & 135 & 148 & 13 & 14 & NS \\
\hline $\mathrm{M} / 0 \cdot 5 \mathrm{M}$ & 126 & 233 & 107 & 44 & NS \\
\hline $\mathbf{M} / 0.25 \mathrm{M}$ & 134 & 437 & 303 & 23 & $0 \cdot 006$ \\
\hline LSD & - & - & 88 & - & - \\
\hline \multicolumn{6}{|c|}{ NEFA entry rate $(\mu \mathrm{mol} / \mathrm{h}$ per $\mathrm{kg})$} \\
\hline $\mathrm{M} / \mathrm{M}$ & 135 & 136 & 1 & $7 \cdot 5$ & NS \\
\hline $\mathrm{M} / 0.5 \mathrm{M}$ & 91 & 140 & 49 & $8 \cdot 4$ & $0 \cdot 031$ \\
\hline $\mathrm{M} / 0 \cdot 25 \mathrm{M}$ & 145 & 362 & 217 & 5.9 & 0.001 \\
\hline LSD & - & - & 22 & 一 & - \\
\hline \multicolumn{6}{|c|}{ Plasma glycerol $(\mu \mathrm{mol} / 1)$} \\
\hline $\mathrm{M} / \mathrm{M}$ & $20 \cdot 1$ & $20 \cdot 6$ & -0.9 & 0.8 & NS \\
\hline $\mathrm{M} / 0.5 \mathrm{M}$ & $19 \cdot 9$ & $26 \cdot 7$ & 6.8 & $4 \cdot 1$ & NS \\
\hline $\mathbf{M} / 0.25 \mathrm{M}$ & $22 \cdot 7$ & $29 \cdot 2$ & 6.5 & $4 \cdot 4$ & NS \\
\hline LSD & - & - & $10 \cdot 4$ & 一 & - \\
\hline \multicolumn{6}{|c|}{ Plasma NEFA: glycerol } \\
\hline $\mathrm{M} / \mathrm{M}$ & $6 \cdot 6$ & $7 \cdot 6$ & 1.0 & 0.91 & NS \\
\hline $\mathrm{M} / 0.5 \mathrm{M}$ & 64 & $8 \cdot 8$ & $2 \cdot 4$ & 1.63 & NS \\
\hline $\mathrm{M} / 0.25 \mathrm{M}$ & $5 \cdot 9$ & $15 \cdot 7$ & $9 \cdot 8$ & $3 \cdot 10$ & 0.087 \\
\hline LSD & -- & - & $6 \cdot 3$ & - & - \\
\hline
\end{tabular}

LSD, least significant difference $(P=0.05)$ based on the error mean square in the analysis of variance; NS, not significant.

* Paired $t$ test.

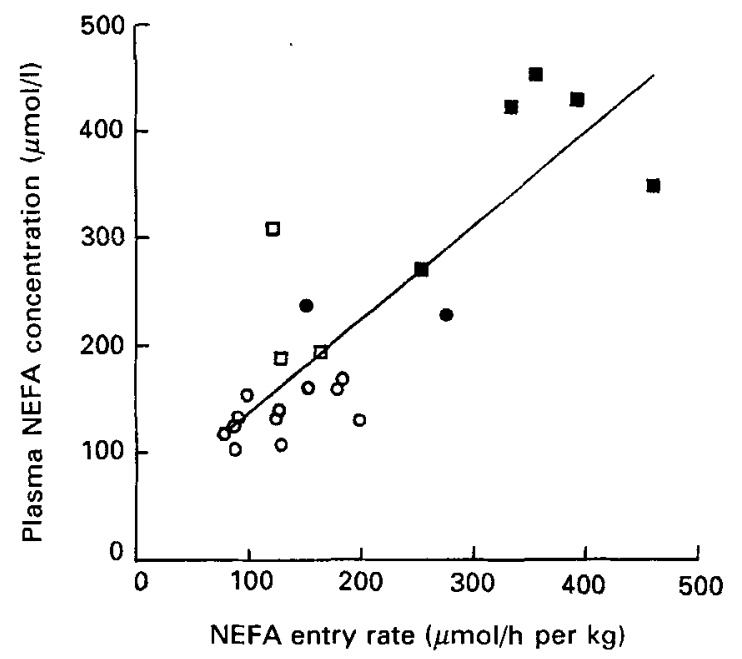

Fig. 2. Relation between plasma non-esterified fatty acid (NEFA) concentrations and NEFA entry rate in goats fed on $140(\mathrm{O}), 100(\bigcirc), 70(\square)$ or $35(\square) \mathrm{kJ}$ metabolizable energy $/ \mathrm{kg}$ per d $(Y=52 \cdot 2+0 \cdot 857$ $X, R 0.841)$.

NEFA entry rate was correlated less strongly with calculated energy balance $\left(R^{2} 0.45, P\right.$ $<0.01$ ).

Chronic undernutrition resulted in changes in the individual molar percentages of NEFA. The oleic acid content increased from 28.9 (SE 0.8$) \%$ to 35.6 (SE 0.5$) \%$ whereas 


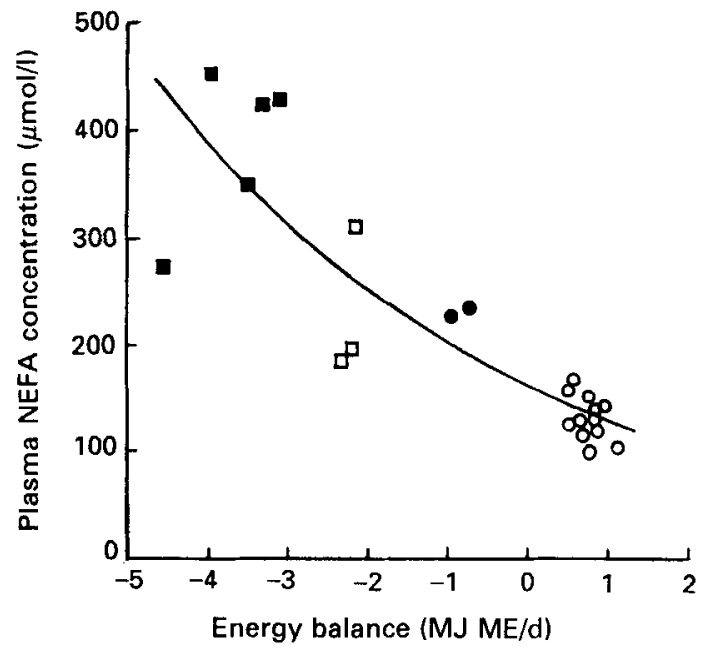

Fig. 3. Relation between plasma non-esterified fatty acid (NEFA) concentrations and energy balance in goats fed on $140(\bigcirc), 100(\bigcirc), 70(\square)$ or $35(\square) \mathrm{kJ}$ metabolizable energy $/ \mathrm{kg}$ per d $\left(Y=160 \mathrm{e}^{-0 \cdot 222 x}\right.$, $R-0.894)$.

Table 2, Regressions of the weight of body components on tritiated water space (TS) and $24 \mathrm{~h}$ fasted live weight (FLWT) in eleven non-lactating, non-pregnant goats

\begin{tabular}{|c|c|c|c|c|c|c|c|c|}
\hline Component & $\begin{array}{c}\text { Equation } \\
\text { no. }\end{array}$ & Model & $a$ & $b$ & $c$ & $\begin{array}{l}\mathrm{RSD} \\
(\mathrm{kg})\end{array}$ & $\begin{array}{l}\mathrm{RCV} \\
(\%)\end{array}$ & $R^{2}$ \\
\hline $\begin{array}{l}\text { Total body } \\
\text { water }(\mathrm{kg})\end{array}$ & $\begin{array}{l}1 \\
2 \\
3 \\
4\end{array}$ & $\begin{array}{l}a+b \text { TS } \\
a \mathrm{TS}^{b} \\
a+b \text { FLWT } \\
a \mathrm{TS}^{b}\end{array}$ & $\begin{array}{c}-1 \cdot 50 \\
0.540 \\
4.48 \\
1.02\end{array}$ & $\begin{array}{l}0.919 \\
1 \cdot 14 \\
0.443 \\
0.841\end{array}$ & $\begin{array}{l}- \\
-\end{array}$ & $\begin{array}{l}1 \cdot 32 \\
0.97 \\
2 \cdot 30 \\
1.66\end{array}$ & $\begin{array}{c}6 \cdot 54 \\
4 \cdot 81 \\
11 \cdot 4 \\
8 \cdot 23\end{array}$ & $\begin{array}{l}0.957 \\
0.974 \\
0.869 \\
0.924\end{array}$ \\
\hline $\begin{array}{l}\text { Empty body } \\
\text { fat }(\mathrm{kg})\end{array}$ & $\begin{array}{l}5 \\
6 \\
7\end{array}$ & $\begin{array}{l}a+b \text { FLWT } \\
a+b \text { FLWT } \\
+c \text { TS } \\
a+b \text { FLWT } \\
+c \log _{\mathrm{e}} \text { TS }\end{array}$ & $\begin{array}{c}-5 \cdot 81 \\
0 \cdot 000 \\
26 \cdot 2\end{array}$ & $\begin{array}{l}0 \cdot 414 \\
0.750\end{array}$ & $\begin{array}{l}-\overline{0.751} \\
-14.0\end{array}$ & $\begin{array}{l}2 \cdot 56 \\
1 \cdot 02\end{array}$ & $\begin{array}{r}29 \cdot 0 \\
11.6 \\
8.91\end{array}$ & $\begin{array}{l}0.823 \\
0.975\end{array}$ \\
\hline $\begin{array}{l}\text { Empty body } \\
\text { protein }(\mathrm{kg})\end{array}$ & $\begin{array}{l}8 \\
9\end{array}$ & $\begin{array}{l}a+b \text { FLWT } \\
a \text { FLWT }^{b}\end{array}$ & $\begin{array}{l}0.599 \\
0.159\end{array}$ & $\begin{array}{l}0.091 \\
0.891\end{array}$ & - & $\begin{array}{l}0.32 \\
0.22\end{array}$ & $\begin{array}{l}8.47 \\
5.75\end{array}$ & $\begin{array}{l}0.934 \\
0.966\end{array}$ \\
\hline $\begin{array}{l}\text { Empty body } \\
\text { ash }(\mathrm{kg})\end{array}$ & $\begin{array}{l}10 \\
11\end{array}$ & $\begin{array}{l}a+b \text { FLWT } \\
a \text { FLWT }^{b}\end{array}$ & $\begin{array}{r}-0.074 \\
0.035\end{array}$ & $\begin{array}{l}0.035 \\
0.981\end{array}$ & - & $\begin{array}{l}0 \cdot 19 \\
0 \cdot 16\end{array}$ & $\begin{array}{l}16 \cdot 1 \\
13 \cdot 4\end{array}$ & $\begin{array}{l}0.862 \\
0.893\end{array}$ \\
\hline
\end{tabular}

$\mathrm{RSD}$, residual standard deviation; $\mathrm{RCV}$, residual coefficient of variation.

linoleic acid decreased from 7.0 (SE 0.6 ) $\%$ to 3.8 (SE 0.3 ) \% of total NEFA when energy intake was changed from $\mathrm{M}$ to $0.25 \mathrm{M}(P<0.01)$. The ratios of molar percentage of stearic acid:oleic acid (S:O) and the sum of stearic and linoleic acids:oleic acid (SL:O) were inversely related to plasma NEFA concentrations $\left(R^{2} 0.46\right.$ and 0.64 respectively) and positively correlated with calculated energy balance $\left(R^{2} 0.54\right.$ and 0.66 respectively).

\section{Body composition}

Total body water (TBW) and TS were highly correlated, with both the linear and the allometric models having high $R^{2}$ and low residual coefficients of variation (RCV) and standard deviations (RSD) (Table 2, eqns (1) and (2)). The linear model overestimated TBW by $8 \%$. 
Table 3. Changes in predicted body composition and non-esterified fatty acid $(N E F A)$ entry rate $(\mathrm{g} / \mathrm{d})$ when the feed intake of three groups of goats was changed from $140(M)$ to 140 $(\mathrm{M}), 70(0.5 \mathrm{M})$ or $35(0.25 \mathrm{M}) \mathrm{kJ}$ metabolizable energy/kg per d

\begin{tabular}{lccccc}
\hline \hline Treatment group... & M & $0.5 \mathrm{M}$ & $0.25 \mathrm{M}$ & $\mathrm{df}$ & LSD \\
\hline No. of goats & 3 & 3 & 3 & - & - \\
$\Delta$ Fasted live wt & $1 \cdot 7$ & $-32 \cdot 3$ & -148 & 6 & $54 \cdot 9$ \\
$\Delta$ Empty body fat & $-4 \cdot 0^{*}$ & $-23 \cdot 8$ & $-75 \cdot 2$ & 5 & $33 \cdot 8$ \\
$\Delta$ Empty body protein & -0.83 & $-3 \cdot 02$ & $-14 \cdot 1$ & 6 & $5 \cdot 37$ \\
$\Delta$ NEFA entry rate & $-2 \cdot 2$ & $12 \cdot 6$ & $51 \cdot 5$ & 6 & $16 \cdot 8$ \\
\hline
\end{tabular}

$\Delta$, Change.

LSD, least significant difference $(P=0.05)$ based on the error mean square in the analysis of variance.

* Mean for two goats.

Table 4. Regressions between decreases in body fat ${ }^{*}$ and plasma non-esterified fatty acid (NEFA) concentrations ([NEFA]), NEFA entry rate (NEFA ER), increases in $[N E F A]$ or $N E F A E R$ and decreases in $24 \mathrm{~h}$ fasted live weight (FLWT) in eight non-lactating, nonpregnant goats

\begin{tabular}{|c|c|c|c|c|}
\hline Model & $a$ & $b$ & $\begin{array}{c}\text { RSD } \\
(\mathrm{g} / \mathrm{d})\end{array}$ & $R^{2}$ \\
\hline$a+b[\mathrm{NEFA}] \dagger$ & $-26 \cdot 9$ & $0 \cdot 226$ & $15 \cdot 0$ & 0.78 \\
\hline$a+b \Delta[\mathrm{NEFA}] \dagger$ & 2.94 & $0 \cdot 223$ & $15 \cdot 3$ & 0.77 \\
\hline$a+b$ NEFA ER $\ddagger$ & $-23 \cdot 6$ & 1.05 & 11.6 & 0.87 \\
\hline$a+b \Delta$ NEFA ER $\ddagger$ & 8.96 & $1 \cdot 24$ & $12 \cdot 0$ & 0.86 \\
\hline$a+b \Delta \mathrm{FLWT}$ & $9 \cdot 37$ & 0.417 & $15 \cdot 5$ & 0.77 \\
\hline
\end{tabular}

RSD, residual standard deviation.

* Determined using eqn (7) from Table 2.

$\dagger \mu \mathrm{mol} / \mathrm{l}$.

$\neq \mathrm{g} / \mathrm{d}$.

FLWT alone was a poor predictor of EB fat (EBF) with an RCV of $29 \%$ (eqn (5), Table 2 ). As there was a high inverse correlation between the percentage of fat and water in the EB, inclusion of TS with FLWT improved the prediction of EBF (eqns (6) and (7), Table 2). Allometric models with FLWT as the predictor provided the best estimates of both EB protein (EBP) and EB ash (EBA) (eqns (9) and (11), respectively, Table 2). Inclusion of TS did not improve the prediction of either EBP or EBA (not shown).

Changes in body composition. The changes in body composition between estimates of TS are summarized in Table 3. EBF and EBP were predicted using the equations with the greatest precision for each component (eqns (7) and (9) respectively, Table 2). Goats fed at either M, $0.5 \mathrm{M}$ or $0.25 \mathrm{M}$ lost an average of $-2,32$ and $148 \mathrm{~g}$ FLWT/d which included an estimated 4,24 and $75 \mathrm{~g}$ fat $/ \mathrm{d}$ and $0 \cdot 8,3$ and $14 \mathrm{~g}$ protein/d respectively. The corresponding mean increases in NEFA entry rate were $-2,13$ and $52 \mathrm{~g} / \mathrm{d}$.

There was a highly significant $(P<0.001)$ correlation between estimated body fat loss and change in NEFA entry rate. Importantly, the changes in both factors were of a similar magnitude (Table 4, Fig. 4). The intercept of the regression equation was not significantly different from zero and when the regression line was constrained to pass through zero the slope of the curve was $1 \cdot 5$. Changes in body fat were also highly correlated with plasma NEFA concentration and changes in live weight (Table 4). 


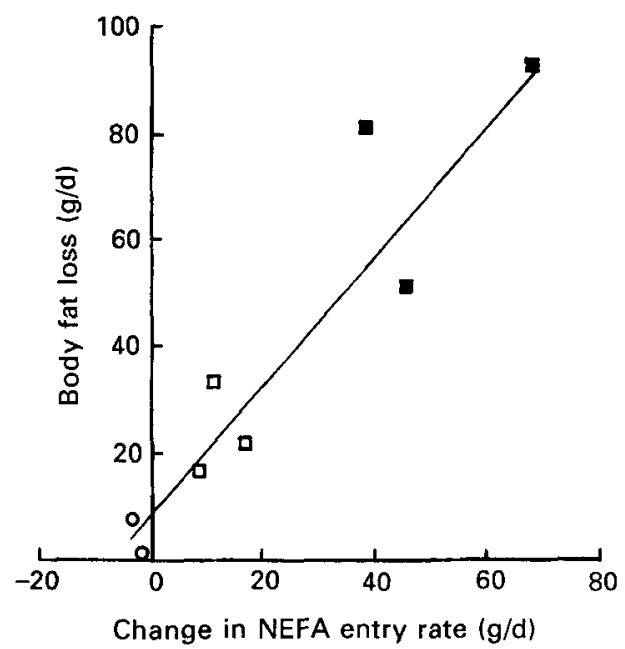

Fig. 4. Relation between estimated body fat loss and change in non-esterified fatty acid (NEFA) entry rate in goats when feed offered was changed from 140 to $140(\mathrm{O}), 70(\square)$ or $35(\square) \mathrm{kJ}$ metabolizable energy $/ \mathrm{kg}$ per d $(Y=8.96+1.24 X, R 0.927)$.

\section{DISCUSSION}

The technique used to determine NEFA entry rate in the present study, involving infusion of a mixture containing equal amounts (activities and molar concentrations) of [1${ }^{14} \mathrm{C}$ palmitic, stearic and oleic acids, was employed in an attempt to minimize any heterogeneity in the behaviour of individual NEFA. This approach was proposed by Bell \& Thompson (1979) who infused a mixture of $1-{ }^{14} \mathrm{C}$-labelled NEFA in the proportions commonly observed in bovine plasma as a tracer for NEFA in steers and found plasma NEFA concentrations and entry rates to be correlated with an $R^{2}$ of 0.69 . A similar correlation was found in the present study. Other workers have observed high correlations between plasma NEFA concentrations and NEFA entry rate as assessed by a continuous infusion of a single labelled NEFA, generally $\left[1-{ }^{14} \mathrm{C}\right]$ palmitic acid (West \& Annison, 1964; Eisemann et al. 1986). Some researchers have reported that the gradient of the line describing the relation between individual plasma NEFA and their respective entry rates is lower for palmitic acid than for stearic or oleic acids (Leat \& Ford, 1966; Annison et al. 1967; Lindsay, 1978). On the other hand, Pethick et al. (1983) reported that in pregnant sheep a single linear equation described the relation between plasma concentrations of palmitic, stearic and oleic acids and their respective entry rates. However, these findings contained only one experiment in which $\left[1-{ }^{14} \mathrm{C}\right]$ palmitic acid was infused into a sheep with the lowest plasma NEFA concentrations. In a more recent paper, Pethick et al. (1987) confirm that $\left[1-{ }^{14} \mathrm{C}\right]$ oleic and $\left[1-{ }^{14} \mathrm{C}\right]$ stearic acids provide similar estimates of NEFA entry rate in non-lactating, non-pregnant sheep. The regression line describing the present relation in goats was intermediate between those of palmitic and oleic acids in sheep (Annison et al. 1967), suggesting that the individual NEFA may not behave as a homogenous unit. Therefore, a mixture of labelled NEFA may be a more representative tracer for quantification of total NEFA entry rate, although a single tracer, for example [1${ }^{14} \mathrm{C}$ ]palmitic acid, is probably adequate where treatment effects on NEFA metabolism are being sought.

High correlations have been found between pre-feeding plasma NEFA levels and productive performance in pregnant sheep (Reid \& Hinks, 1962a). This led Russel et al. 
(1967) to suggest use of plasma NEFA levels as the criterion by which to maintain ewes in certain prescribed nutritional states during late pregnancy. Holmes \& Lambourne (1970) found that energy intake was highly correlated with plasma NEFA concentrations in beef steers and heifers fed every $4 \mathrm{~h}\left(R^{2} 0.93\right)$. High correlations were also found between prefeeding NEFA levels and energy status in non-lactating, pregnant and non-pregnant cows $\left(R^{2}>0 \cdot 89\right.$, Russel \& Wright, 1983). In addition, both plasma NEFA concentrations and NEFA entry rate were correlated with energy balance in lactating goats $\left(R^{2} 0.65\right.$ and 0.64 respectively, Dunshea \& Bell, 1987) and dairy cows $\left(R^{2} 0.61\right.$ and 0.41 respectively, Bauman et al. 1988). The correlation found in the present work $\left(R^{2} 0.80\right)$ was not as high as that calculated by Holmes \& Lambourne (1970) or Russel \& Wright (1983). Nevertheless, it provides confidence that plasma NEFA levels reflect energy status in non-lactating, nonpregnant goats. Also, the findings of Russel \& Wright (1983) appear to have been averaged for each level of feeding before fitting regression equations. The regression analyses in the present study and in that of Holmes \& Labourne (1970) used individual data points.

The plasma concentrations of NEFA found in the present study were lower than those reported in most other papers. This is presumably because the goats were fed every $2 \mathrm{~h}$ and consequently plasma NEFA concentrations and entry rates were in a relatively steady state. Most researchers have used the plasma concentrations of NEFA in prefeeding samples obtained from animals fed once daily (Reid \& Hinks, 1962 b; Russel et al. 1967; Russel \& Wright, 1983). Russel et al. (1967) found that in sheep fed once daily, the pre-feeding NEFA levels were three to five times greater than post-feeding concentrations. These fluctuations are most pronounced in animals fed on restricted rations (Reid \& Hinks, 1962c; Miller et al. 1978; Bines \& Morant, 1983). The regression equation for energy balance $v$. plasma NEFA levels in the non-lactating, non-pregnant cows of Russel \& Wright (1983) predicts a plasma concentration of $450 \mu \mathrm{mol} / 1$ at maintenance. The corresponding concentration from the present work was $160 \mu \mathrm{mol} / 1$, further emphasizing the relation between feeding frequency and NEFA metabolism.

Fasting has been shown to result in a decreased S:O value for plasma NEFA (Jackson \& Winkler, 1970; Thompson et al. 1975) and Vernon (1981) suggested that this ratio may reflect energy status. Likewise, this ratio decreased during chronic undernutrition in these goats and was related to both plasma NEFA concentrations and calculated energy balance. The decrease in $\mathrm{S}: \mathrm{O}$ of plasma NEFA during fasting or prolonged undernutrition probably occurs because adipose tissue triglycerides generally have a lower S:O than plasma NEFA (Christie, 1981), even more so during fasting (Jackson \& Winkler, 1970). This, combined with a small, rapidly turning over plasma pool of NEFA, means that any increase in the entry of NEFA from adipose tissue triglycerides will be associated with a decrease in the $\mathrm{S}: \mathrm{O}$ of plasma NEFA. The rapidity with which this can occur is evident from the work of Noble et al. (1969) where intravenous injection of noradrenaline into sheep resulted in a sharp increase in plasma NEFA and a decrease in S:O of plasma NEFA. The decrease in the linoleic acid content of plasma NEFA during chronic undernutrition is consistent with what occurs in fasted sheep (Jackson \& Winkler, 1970; Lindsay \& Leat, 1977). Lindsay \& Leat (1977) suggested that linoleic acid is conserved during undernutrition in sheep, possibly through preferential limitation of its hepatic oxidation (Reid \& Husbands, 1985).

The use of FLWT alone as a predictor for EBF resulted in a low correlation, probably due to the wide range in EBF $(40-400 \mathrm{~g} / \mathrm{kg}$ EB weight). Inclusion of TS improved the accuracy of estimation of EBF, decreasing the RSD (RCV) from $2.56 \mathrm{~kg}(29.0 \%)$ to $1.02 \mathrm{~kg}$ $(11.6 \%)$ and $0.79 \mathrm{~kg}(8.9 \%)$ for eqns (5), (6) and (7) (Table 2) respectively. RCV (\%) for prediction of EBF from live weight and TS in non-lactating, non-pregnant ruminants were 10.1 (Bird et al. 1982) for cattle, 4.0 (Panaretto, 1963), 4.7 (Donnelly \& Freer, 1974) and 
11.9 (Trigg et al. 1978) for sheep and 17.7 (Panaretto, 1963) and 17.8 (Panaretto \& Till, 1963 ) for goats. Brown \& Taylor (1986) were able to predict EBF in ten lactating and five non-lactating goats using live weight and deuterium oxide space estimated by zero-time extrapolation with an $\mathrm{RCV}$ of $14.2 \%$.

The magnitude of the RSD for the prediction of EBF in the present work is such that a considerable period of time would be necessary to detect changes reliably in EBF in response to chronic undernutrition. Other factors, besides FLWT and TS, could contribute towards the residual component of the prediction equation for EBF, including age or an index of skeletal development, or both (Donnelly \& Freer, 1974). However, the goats in the present study were mature, so this component should have remained constant for a particular goat over the course of the present study and any bias in estimation of body composition in a particular anthal should have been constant. For this reason, serial estimates of changes in body composition in an individual animal are probably more reliable than the RSD would indicate. This is borne out by the high correlations between NEFA kinetics and estimated losses of body fat in individual goats.

Panaretto (1964) fed six sheep of moderate body fatness $(240 \mathrm{~g} / \mathrm{kg}$ live weight) and similar live weight to the goats used in the present experiment, decreasing amounts of lucerne chaff-oaten grain $(1: 1, \mathrm{w} / \mathrm{w})$. Body composition was predicted from TOH dilution at days $0,56,102$ and 142 of undernutrition. Assuming that the DM and ME contents of the diet were the same as found here, the average daily $M E$ intakes for these sheep were approximately 80,50 and $35 \mathrm{~kJ} \mathrm{ME} / \mathrm{kg} 48 \mathrm{~h}$ FLWT over the three periods between determinations of $\mathrm{TOH}$ dilution. Average body-fat losses over these periods were 30,38 and $76 \mathrm{~g} / \mathrm{d}$ respectively. These $\mathrm{ME}$ intakes and corresponding estimated body-fat losses, with the exception of those in the second period, were very similar to those observed in the present study.

Evidence that plasma kinetics quantitatively reflect lipid mobilization in the long term is provided in Fig. 4. Changes in EBF were highly correlated with changes in NEFA entry rate. More importantly, the magnitude of the changes were of a similar order. The slope of the line describing this relation suggests that the changes in NEFA kinetics underestimate changes in EBF by approximately $30 \%$. Lipid mobilization is the net result of the balance between lipogenesis, lipolysis and re-esterification of NEFA released during lipolysis. The NEFA entry rate reflects the entry of NEFA into the circulation but gives no indication of the re-esterification of NEFA. An estimate of the apparent re-esterification of NEFA released after hydrolysis of adipose-tissue triglycerides can be obtained by simultaneously determining NEFA and glycerol entry rates (Wilson, 1983, 1984; Dunshea \& Bell, 1987). If the rate of re-esterification remains constant then the rate of glycerol entry into the bloodstream should parallel the NEFA entry rate. As glycerol comprises approximately $10 \%$ of the weight of a triglyceride molecule, this is a possible source of the discrepancy between EBF loss determined by TOH dilution and by NEFA kinetics. However, plasma glycerol concentrations did not increase significantly, while the ratio plasma NEFA: glycerol tended to increase during chronic undernutrition. If, as generally accepted, plasma glycerol concentrations reflect the entry rate of glycerol (Bergman, 1968), it appears that re-esterification of NEFA may have decreased during energy restriction and that glycerol is not a major portion of the increase in fat mobilization. In this context, NEFA re-esterification was decreased during early lactation and was positively correlated with energy balance in lactating goats (Dunshea \& Bell, 1987).

Net fat mobilization can also occur if the rate of lipogenesis is decreased, without any change in the rate of lipolysis. Lipogenesis is very much dependent on the supply of precursors for triglyceride synthesis in adipose tissue, principally acetate and glucose in ruminants. During restricted feeding the circulating levels of both acetate (Annison \& 
White, 1962; Annison et al. 1968; Bergman \& Wolff, 1971) and glucose (Bergman et al. 1974 ) decrease. In vitro adipose lipogenesis also decreases after feed restriction (Ingle $e t$ al. 1973; Hood \& Thornton, 1980). Therefore, decreased lipogenesis may well be the major source of the discrepancy between changes in estimated EBF and NEFA entry rates.

The findings reported in the present study demonstrate that NEFA kinetics quantitatively reflect lipid mobilization in non-lactating, non-pregnant goats. There was a high correlation between changes in EBF estimated by TOH dilution and changes in NEFA entry rate, although the latter tended to quantitatively underestimate the former. This discrepancy was probably due to changes in adipose tissue lipogenesis and, to a lesser extent, the contribution of triglyceride glycerol to lipid mobilization. It is suggested that control of the rate of re-esterification of NEFA released during lipolysis may be involved in regulation of lipid metabolism during clironic undernutrition.

The authors wish to thank Mr K. D. Chandler and Miss R. Fitzpatrick for technical assistance and care of the animals. F.R.D. was supported by a grant from the Australian Dairy Research Committee.

\section{REFERENCES}

Aitkinson, T., Fowler, V. R., Garton, G. A. \& Lough, A. K. (1972). Analyst 97, 562-..568.

Anderson, L. E. \& MacClure, W. O. (1973). Analytical Biochemistry 51, 173-179.

Annison, E. F. (1960). Australian Journal of Agricultural Research 11, 58-64.

Annison, E. F., Brown, R. E., Leng, R. A., Lindsay, D. B. \& West, C. E. (1967). Biochemical Journal 104, $135-147$.

Annison, E. F., Linzell, J. L. \& West, C. E. (1968). Journal of Physiology 197, 445459

Annison, E. F. \& White, R. R. (1962). Biochemical Journal 84, 546-552.

Armstrong, D. G. \& Blaxter, K. L. (1965). In Energy Metaholism, pp. 59-72 [K. L. Blaxter, editor]. London: Academic Press.

Bauman, D. E., Peel, C. J., Steinhour, W. D., Reynolds, P. J., Tyrrell, H. F., Brown, A. C. G. \& Haaland, G. L. (1988). Journal of Nutrition 118, 1031-1040

Bell, A. W. \& Thompson, G. E. (1979). American Journal of Physiology 237, E309-E315.

Benedict, R. C. (1987). Journal of the Association of Official Analytical Chemists 70, 69-74

Bergman, E. N. (1968). American Journal of Physiology 215,865-873.

Bergman, E. N., Brockman, R. P. \& Kaufman, C. F. (1974). Federation Proceedings 33, 1849-1854.

Bergman, E. N. \& Wolfi, J. E. (197I). American Joumal of Physiology 221. 586-592.

Bines, J. A. \& Morant, S. V. (1983). British Journal of Nutrition 50,81-89.

Bird, P. R., Flinn, P. C., Cayley, J. W. D. \& Watson, M. I. (1982). Australion Journal of Agricultural Research 33, 375-388.

Boobis, L. H. \& Maughan, R. J. (1983). Clinica Chemica Acta 132, 173-179.

Brown, D. L. \& Taylor, S. J. (1986). Journal of Dairy Science 69, 1151-1155.

Christie, W. W. (1981). In Lipid Metabolism in Ruminant Animals, pp. $95-192$ [W. W. Christie, editor]. Oxford: Pergamon Press.

Di Marco, N. M., Beitz, D. C. \& Whitehurst, G. B. (1981). Journal of Science 52, 75-82.

Donnelly, J. R. \& Freer, M. (1974). Australian Journal of Agricultural Research 25, 825-834.

Dunshea, F. R. \& Bell, A. W. (1987). Journal of Dairy Science 70, Suppl., p. 10.

Eisemann, J. H., Hammond, A. C., Bauman, D. E., Reynolds, P. J., McCutcheon, S. N., Tyrrell, H. F. \& Haaland, G. L. (1986). Journal of Nutrition 116, 2504-2515.

Farrell, D. J., Leng, R. A. \& Corbett, J. L. (1972). Australian Journal of Agricultural Research 23, $483-497$.

Hassan, B. H. A. T. \& Musa, N. (1984). Comparative Biochemistry and Physiology 79A, 325-328.

Holmes, J. H. G. \& Lambourne, L. J. (1970). Research in Veterinary Science 11, 27-36.

Hood, R. L. \& Thornton, R. F. (1980). Australian Journal of Agricultural Science 31, 155-161.

Ingle, D. L., Bauman, D. E., Mellenberger, R. W. \& Johnson, D. E. (1973). Journal of Nutrition 103, $1479-1488$.

Jackson, H. D. \& Winkler, V. W. (1970). Journal of Nutrition 100, 201-207.

Leat, W. N. F. \& Ford, E. J. H. (1966). Biochemical Journal 101, 317-322.

Lindsay, D. B. (1978). In The Use of Blood Metabolites in Animal Production, pp: 99-120 [D. Lister, editor]. Thames Ditton: British Society of Animal Production.

Lindsay, D. B. \& Leat, W. N. F. (1977). Journal of Agricultural Science, Cambridge 89, $215-221$.

Miller, T. B., Chigaru, P., Downie, J. G., Galbraith, H., Macdonald, D. C. \& Topps, J. H. (1978). In The Use of 
Blood Metabolites in Animal Production, pp. 71-86 [D. Lister, editor]. Thames Ditton: British Society of Animal Production.

Ministry of Agriculture, Fisheries and Food (1975). Energy Allowances and Feeding Systems for Ruminants, Technical Bulletin, no. 33. London: H.M.S.O.

Noble, R. C., Thompson, G. E. \& Moore, J. H. (1969). Research in Veterinary Science 10, 555-558.

Panaretto, B. A. (1963). Australian Journal of Agricultural Research 14, 944952.

Panaretto, B. A. (1964). Australian Journal of Agricultural Research 15, 771-787.

Panaretto, B. A. (1968). Australian Journal of Agricultural Research 19, 267-272.

Panaretto, B. A. \& Till, A. R. (1963). Australian Journal of Agricultural Research 14, 926-943.

Patterson, D. S. P., Burns, K. N., Cunningham, N. F., Herbert, C. N. \& Saba, N. (1964). Journal of Agricultural Science, Cambridge 62, 253-262.

Pethick, D. W., Harmon, N. \& Chong, J. K. (1987). Australian Journal of Agricultural Science 40, $221-234$.

Pethick, D. W., Lindsay, D. B., Barker, P. J. \& Northrop, A. J. (1983). British Journal of Nutrition 49, 129-143.

Reid, J. C. W. \& Husbands, D. R. (1985). Biochemical Journal 225, 233-237.

Reid, R. L. \& Hinks, N. T. (1962a). Australian Journal of Agricultural Research 13, 1092-1111.

Reid, R. L. \& Hinks, N. T. (1962b). Australian Journal of Agricultural Research 13, 11121123.

Reid, R. L. \& Hinks, N. T. (1962c). Australian Journal of Agricultural Research 13, $1124-1136$.

Russel, A. J. F., Doney, J. M. \& Reid, R. L. (1967). Journal of Agricultural Science, Cambridge 68, $359-363$

Russel, A. J. F. \& Wright, I. A. (1983). Animal Production 37, 335-343.

Ryan, T. A. Jr, Joiner, B. L. \& Ryan, B. F. (1985). Minitab: Version 5.1. Massechusetts: Duxbury Press.

SAS (1982). SAS User's Guide: Statistics. Cary, NC: SAS Institute.

Searle, T. W. (1970). Journal of Agricultural Science, Cambridge 74, 357-362.

Thompson, G. E., Gardner, J. W. \& Bell, A. W. (1975). Quarterly Journal of Experimental Physiology 60, $107-121$.

Trigg, T. E., Domingo, E. A. \& Topps, J. H. (1978). Journal of the Science of Food and Agriculture 29 , 1007-1016.

Vernon, R. G. (1981). In Lipid Metabolism in Ruminant Animals, pp. 279362 [W. W. Christie, editor]. Oxford: Pergamon Press.

West, C. E. \& Annison, E. F. (1964). Biochemical Journal 92, 573-578.

Wilson, S. (1983). Proceedings of the Nutrition Society 42, 130A.

Wilson, S. (1984). Canadian Journal of Animal Science 64, Suppl., 246-247. 